\title{
MATHEMATICAL MODELLING FOR MICROPILES EMBEDDED IN SALT ROCK
}

\begin{abstract}
Georgiana RĂDAN (TOADER) - Engineer, SC Construcţii ERBSU SA, PhD Student, Technical University of Civil Engineering, Faculty of Building Services Engineering, e-mail:georgianatoader@erbasu.ro,

Nicoleta RĂDULESCU - Professor, PhD, Technical University of Civil Engineering Bucharest- Soil Mechanics and Foundations Engineering Department, e-mail: nicoleta@utcb.ro,
\end{abstract}

Gheorghe OANCEA - Engineer, SC CONSIS Proiect SRL, PhD Student, Technical University of Civil Engineering, Faculty of Railways Roads and Bridges, e-mail:oancea.gh@gmail.com.

\begin{abstract}
This study presents the results of the mathematical modelling for the micropiles foundation of an investement objective located in Slanic, Prahova county. Three computing models were created and analyzed with software, based on Finite Element Method. With Plaxis 2D model was analyzed the isolated micropile and the three-dimensional analysis was made with Plaxis 3D model, for group of micropiles. For the micropiles foundation was used Midas GTS-NX model. The mathematical models were calibrated based with the in-situ tests results for axially loaded micropiles, embedded in salt rock. The paper presents the results obtained with the three software, the calibration and validation models.
\end{abstract}

Keywords: micropiles, group, salt rock, mathematical model, Finite Element Method

\section{Introduction}

This paper represents a continuation of the previous study "Micropiles axially loaded in karst terrain",of which was analyzed the in-situ tests results, performed on drilled micropile at Slanic Prahova county, Baia Verde (2009) [1]. In the project has been executed a number of 314 drilled micropiles of $200 \mathrm{~mm}$ diameter, embedded in salt rock, minimum three diameters. Micropiles were executed in type A: drilled micropiles by entering the fluid in the drilling hole, gravitationaly. According to The Federal Highway Administartion, the classification also including [3]:

- Type B - introducing the drilling fluid under small pressure, by the gradual withdrawal of the temporary drill casing of the hole,

- Type C - the execution is done in two steps: firstly, the drilling fluid is introduced gravitationally similarly to the Type A execution, then, before the consolidation of the drilling fluid, at an interval of about 15-25 minutes, the same type of mortar is injected at the interface with the "bedrock", at the pressure of minim $1 \mathrm{MPa}$, without using the packer,

- Type D - Consists of the repeated injection of the drilling fluid with a pressure between 2-8 $\mathrm{MPa}$

The project location was in a karstic saline zone, which has been the reason for chosen the solution foundations on micropiles, with anticorrosion protection of the elements [1]. Having the in situ tests result, obtained for micropiles in Slanic, the author tried to validate the mathematical model created through an easy spread-sheet obtained as the results of the research by Seo and Prezzi (2008) [2]. Then it was made a comparasion between the micropiles executed in Slanic and the similar one executed in Puerto-Rico. The conclusion of this first study, was the micropiles embedded in salt rock, axially loaded, has similar behavior as micropiles executed with postgrouting in soft soils, because of very good mechanical characteristics of the bedrock. 
Continuing the studies, in this paper, we tried to create and validate the calculation models for groups and foundation on micropiles executed in Slanic Prahova - "Leisure and treatment Base Baia Verde", with software based on Finite Element Method.

The article is structured in three principal parts. First part of the study analyzed the mathematical model of an isolated micropile embedded in salt rock and compared the results obtained with the in-situ tests results in Slanic and the results obtained through an easy spread-sheet. In this case, for the isolated element, two-dimensional FEM analysis was done with Plaxis 2D software. Second part of this paper presents the analyse of micropiles group for central and marginal foundation, made with Plaxis 3D software. The results obtained in the first variants of analysis, conduct to the necessity of checking and calibration calculation model. In the last part of the article, the results obtained for one central axis of foundation on micropiles, are presented. Foundations analysis is more complex, and the software program allowed to create with accuracy the mathematical model.

\section{Calculation models for micropiles}

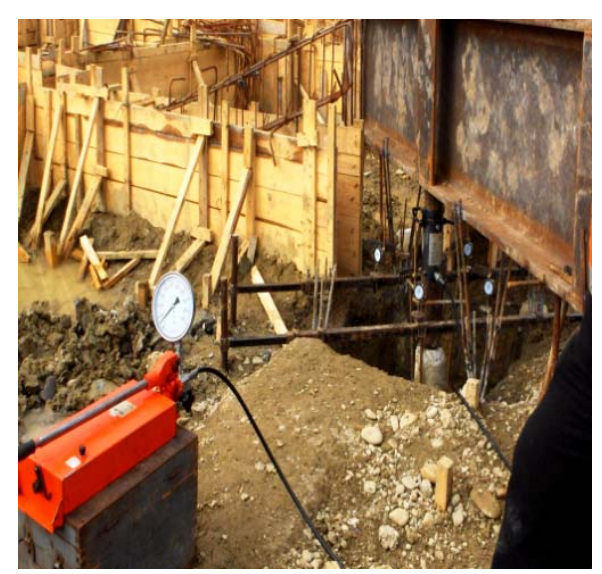

To create calculation models were used information from geotechnical study. The terrain is characterized by stratification layers of some plastic, very consistent and soft clays, wich colour is yellow-brown for the first strata, and some blue clays with gravel intercalations, before the intersection with breccias. The in-situ tests were conducted on a total of five micropiles, for which the results are shown in Figure 2. Axial load on each micropile was applied in increments of $35 \mathrm{kN}, 70 \mathrm{kN}$, $105 \mathrm{kN}, 140 \mathrm{kN}, 175 \mathrm{kN}$ and $210 \mathrm{kN}$.

Fig.1 - The in-situ tests on micropile, Slănic Prahova (2009) [3]

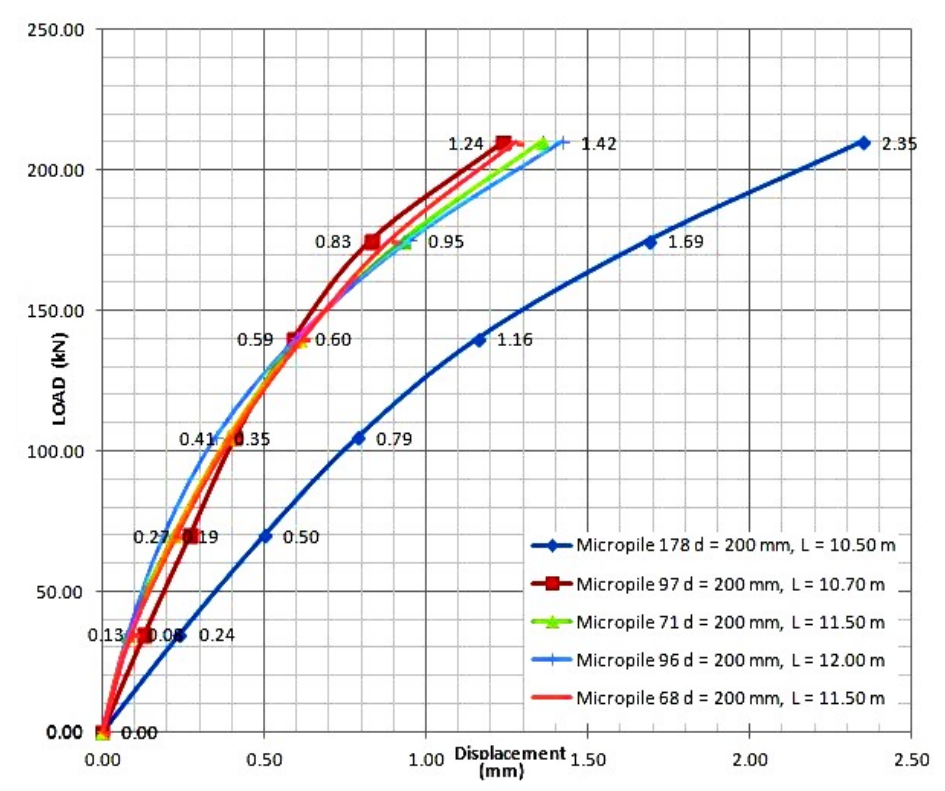

Fig.2 - The graphic presentation of the in-situ tests results on micropiles [3] 


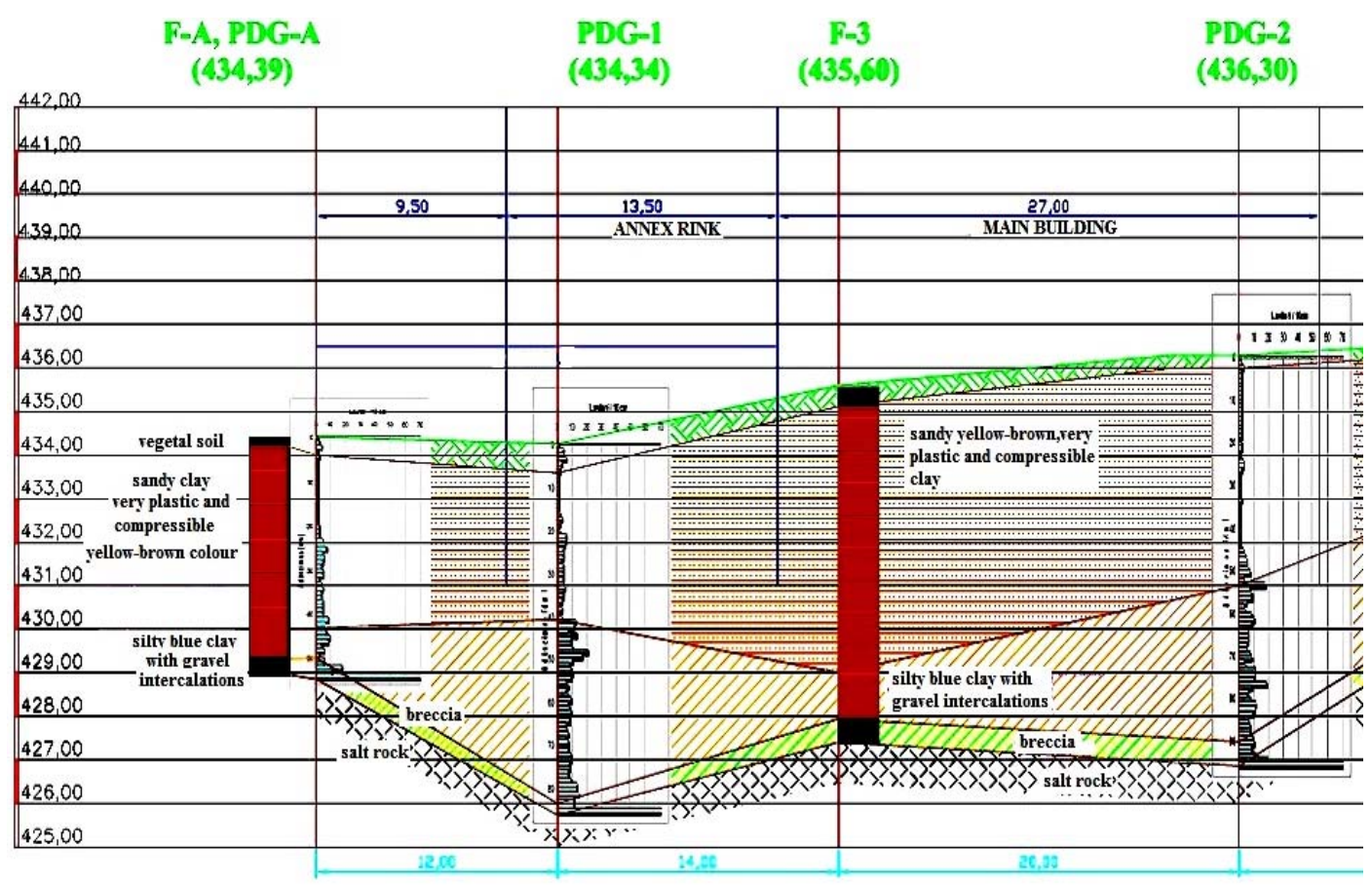

Fig.3 - The lithologic profile I-I, for Main Building [4]

\subsection{Calculation model and results obtained for isolated micropiles}

For the individual element, axially loaded micropile, the modeling and analysis was done with the soft Plaxis 2D. The analysis of the micropile is two dimensional and is performed in the plain strain deformations. For the soil, Mohr-Coulomb model has been used. The behaviour is elastoplastic and requires the input of five basic parameters of the soil: Young's module (E), Poisson's coefficient (v), cohesion (c), the friction angle and the dilatancy $(\phi, \psi)($ Table 1$)$.

The input parameters for soil and micropiles,Plaxis 2D model

\begin{tabular}{|c|c|c|c|c|c|}
\hline \multicolumn{2}{|c|}{ Mohr-Coulomb } & $\begin{array}{c}1 \\
\text { Sare } \\
\end{array}$ & $\begin{array}{c}2 \\
\text { Argila } 1 \\
\end{array}$ & $\begin{array}{c}3 \\
\text { Argila } 2 \\
\end{array}$ & $\begin{array}{c}4 \\
\text { Brecia } \\
\end{array}$ \\
\hline \multicolumn{2}{|c|}{ Type } & Drained & Drained & Drained & Drained \\
\hline$\gamma_{\text {unsat }}$ & {$\left[\mathrm{kN} / \mathrm{m}^{3}\right]$} & 21.00 & 16.00 & 18.00 & 18.50 \\
\hline$\gamma_{\text {sat }}$ & {$\left[\mathrm{kN} / \mathrm{m}^{3}\right]$} & 21.00 & 16.00 & 18.00 & 18.50 \\
\hline $\mathbf{k}_{\mathbf{x}}$ & {$[\mathrm{m} /$ day $]$} & 0.000 & 0.000 & 0.000 & 0.000 \\
\hline $\mathbf{k}_{\mathbf{y}}$ & [m/day $]$ & 0.000 & 0.000 & 0.000 & 0.000 \\
\hline $\mathbf{e}_{\text {init }}$ & {$[-]$} & 0.500 & 0.500 & 0.500 & 0.500 \\
\hline $\mathbf{c}_{\mathrm{k}}$ & {$[-]$} & $1 \mathrm{E} 15$ & $1 \mathrm{E} 15$ & $1 \mathrm{E} 15$ & $1 \mathrm{E} 15$ \\
\hline $\mathbf{E}_{\text {ref }}$ & {$\left[\mathrm{kN} / \mathrm{m}^{2}\right]$} & 3000000.000 & 8500.000 & 12500.000 & 20000.000 \\
\hline$v$ & {$[-]$} & 0.250 & 0.350 & 0.350 & 0.300 \\
\hline $\mathbf{G}_{\text {ref }}$ & {$\left[\mathrm{kN} / \mathrm{m}^{2}\right]$} & 1200000.000 & 3148.148 & 4629.630 & 7692.308 \\
\hline $\mathbf{E}_{\text {oed }}$ & {$\left[\mathrm{kN} / \mathrm{m}^{2}\right]$} & 3600000.000 & 13641.975 & 20061.728 & 26923.077 \\
\hline $\mathbf{c}_{\text {ref }}$ & {$\left[\mathrm{kN} / \mathrm{m}^{2}\right]$} & 5200 & 53.00 & 31.00 & 20.00 \\
\hline$\varphi$ & {$\left[^{\circ}\right]$} & 30.00 & 17.00 & 15.00 & 20.00 \\
\hline$\psi$ & {$\left[{ }^{\circ}\right]$} & 0.00 & 0.00 & 0.00 & 0.00 \\
\hline
\end{tabular}

\begin{tabular}{|c||cccc||}
\hline $\begin{array}{c}\mathbf{R}_{\text {inter. }} \\
{[-]}\end{array}$ & 1.00 & 1.00 & 1.00 & 1.00 \\
\hline $\begin{array}{c}\text { Interface } \\
\text { permeability }\end{array}$ & Neutral & Neutral & Neutral & Neutral \\
\hline
\end{tabular}




\begin{tabular}{||c|c|c|c|c|c|c|c||}
\hline \hline no. & Beam & $\begin{array}{c}\text { EA } \\
{[\mathrm{kN} / \mathrm{m}]}\end{array}$ & $\begin{array}{c}\text { EI } \\
{[\mathrm{kNm} / \mathrm{m}]}\end{array}$ & $\begin{array}{c}\mathbf{w} \\
{[\mathrm{kN} / \mathrm{m} / \mathrm{m}]}\end{array}$ & $\begin{array}{c}\mathbf{v} \\
{[-]}\end{array}$ & $\begin{array}{c}\text { Mp } \\
{[\mathrm{kNm} / \mathrm{m}]}\end{array}$ & $\begin{array}{c}\text { Np } \\
{[\mathrm{kN} / \mathrm{m}]}\end{array}$ \\
\hline 1 & Micropilot & $1.0048 \mathrm{E} 6$ & 3200.00 & 0.79 & 0.20 & $1 \mathrm{E} 15$ & $1 \mathrm{E} 15$ \\
\hline
\end{tabular}

The interface of the micropile with the adjacent soil is modeled automatically in the program, so that it considers the relative slip between the micropile and the soil, by approximating, as exactly as possible, the gradual mobilization of lateral friction [3].

In our case, the strength reduction factor, for rough interface between concrete and soil, $\mathrm{R}_{\text {inter }}$ can be considered equal 1 [13], and the values of the cohesion and friction angle are equals with them of the soil.

From the results of tests on micropiles presented in Figure 2, is seen as micropiles 97,71,96 and 68 respectively, fall in the same interval of displacements to the steps of load applied. The only exception does micropile 178, for which one, we supposed to cross a layer of very soft clay, having inferior mechanical properties compared to the previously mentioned micropile. Therefore we present in the following calculation model for micropile 68, as representative for others micropiles, falling in the same interval of displacements values (fig.4a) and separately the calculation model for micropile 178 (fig.4b). Phase 1 of the calculation model is to define the geometry of soil and its structure, by introducing the characteristic parameters.

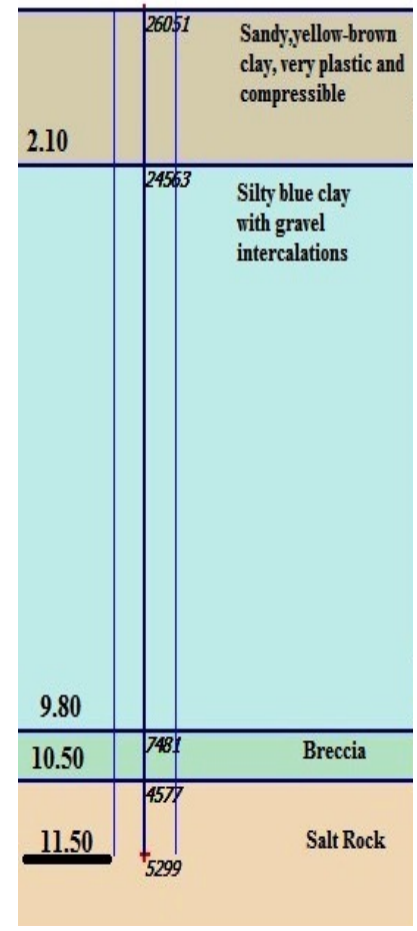

(a)

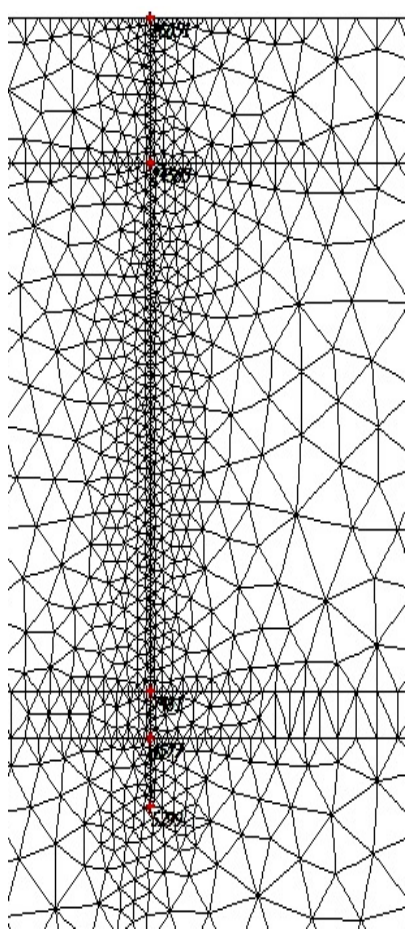

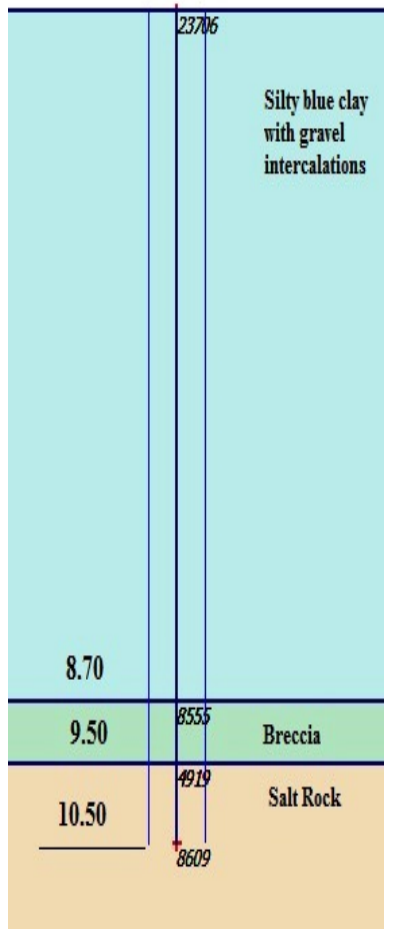

(b)

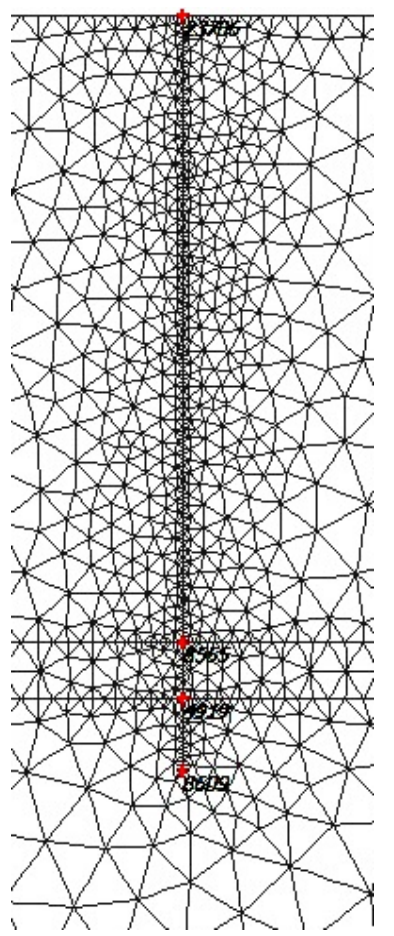

Fig. 4: -The geometry and calculation model for the micropile 68 (a) and the micropile 178 (b) (PLAXIS 2D)[3]

In phase 2 of the calculation model, the micropile is introduced in terrain. In this phase the deformations that appeared are very small: for the micropiles 68 and 71 the displacements values were $48 \times 10-6 \mathrm{~m}$ (fig.6), for micropile 178 we obtained $37.5 \times 10-6 \mathrm{~m}$, for micropile 97 the value of displacement in this phase was $40 \times 10-6 \mathrm{~m}$. It observed the proportional increase of deformations, with the length of micropiles.[3]

The next phases of the analysis, phase 3 to phase 8 , represents the steps of applied axial load from $35 \mathrm{kN}$ to $210 \mathrm{kN}$. 


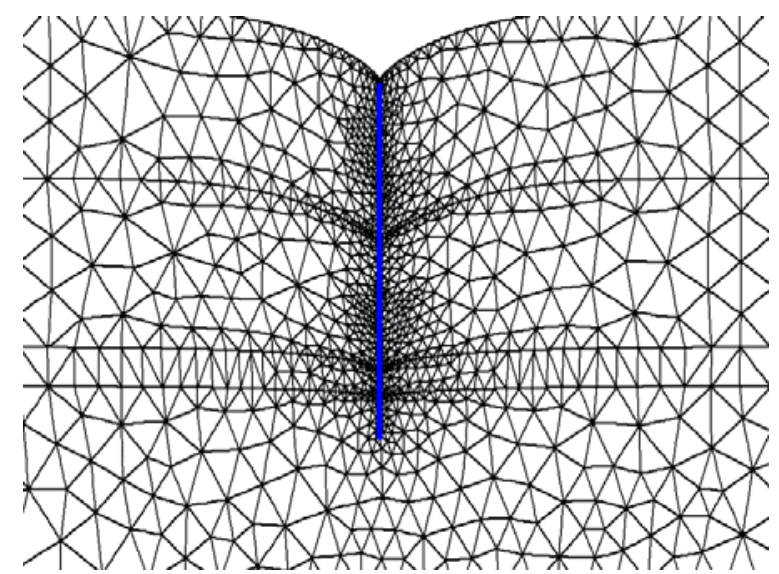

Fig. 5 - Deformed mesh for micropile 68, phase

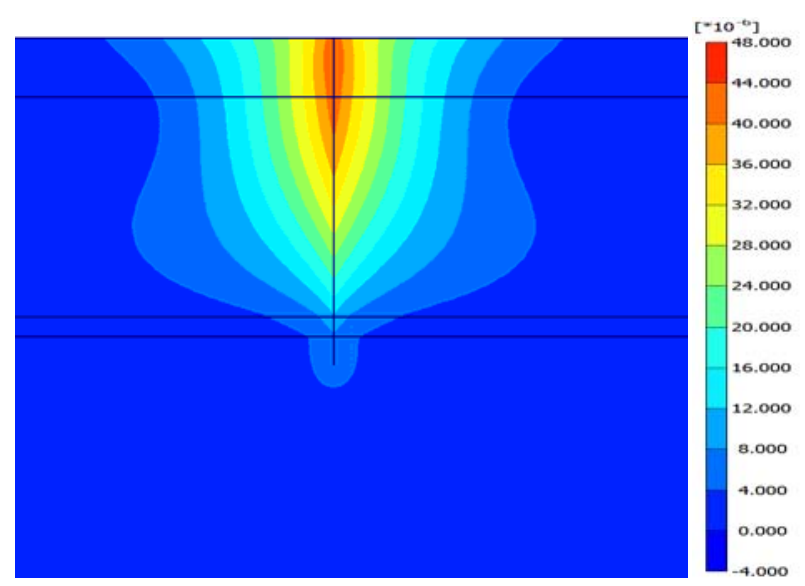

Fig.6 - Total displacements for micropile 68, phase 2[3]

The comparison of the results obtained for micropiles, with Plaxis 2D, and the in-situ tests results is presented in figure 7.
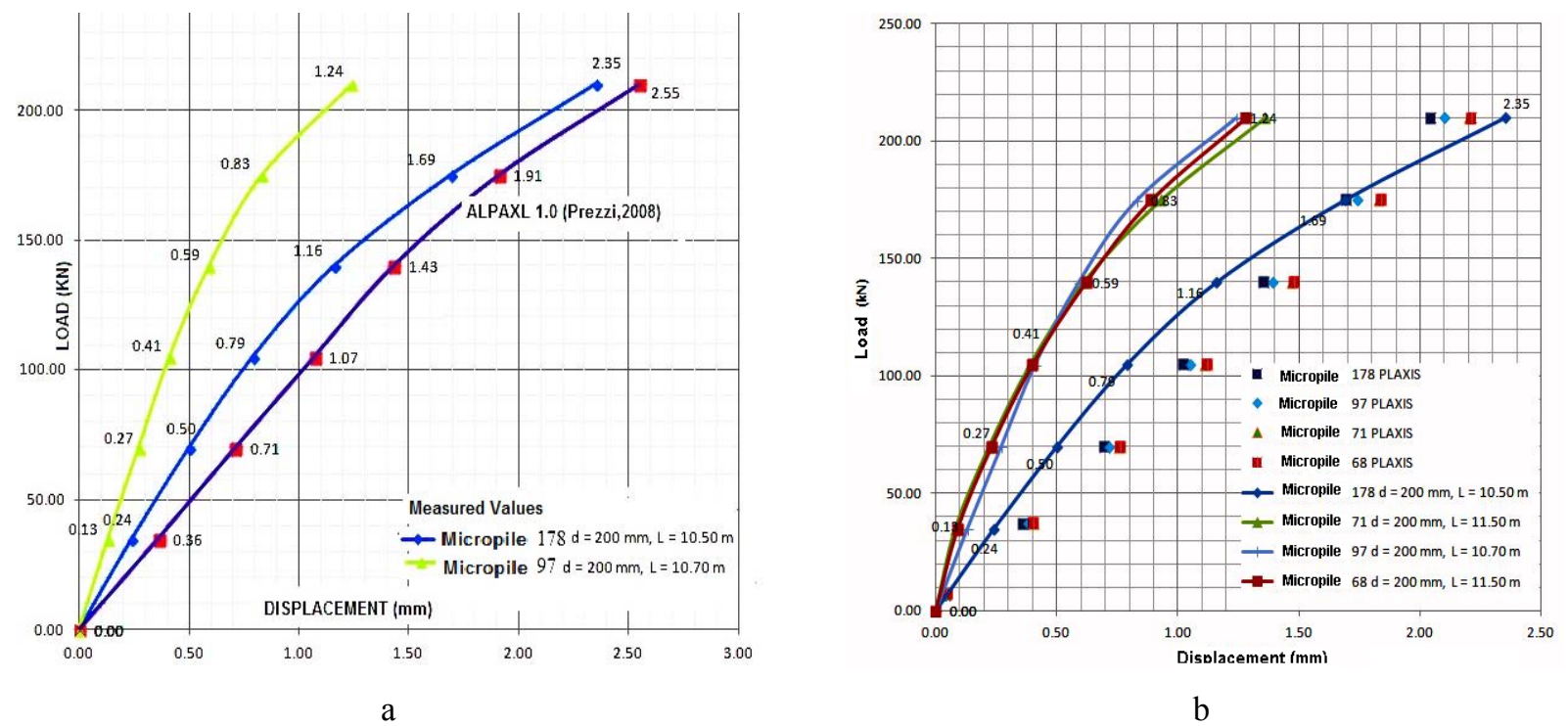

b

Fig.7 - Axially tests results obtained through ALPAXL, PLAXIS 2D software and experimentally for micropiles 178, 97, 71, 68 [3]

The results obtained with Plaxis 2D software are closed to the results obtained by the in-situ tests for micropile 178. For the other micropiles this results of the program are suitable, considering the unpredictable nature of karstic terrains. It can be stated that through the soft PLAXIS 2D there were obtained similar results with those obtained with ALPAXL 1.0 spreadsheet, which follow the value interval of the results on site for the least favourable case, for micropile 178 .

\subsection{Calculation model and results obtained for groups of micropiles}

The calculation model and analyse for the central foundation (the group of five micropiles) and the marginal one (the group of four micropiles), as presented in Figure 8, was used Finite Element Method based on three-dimensional analysis with Plaxis 3D software. 


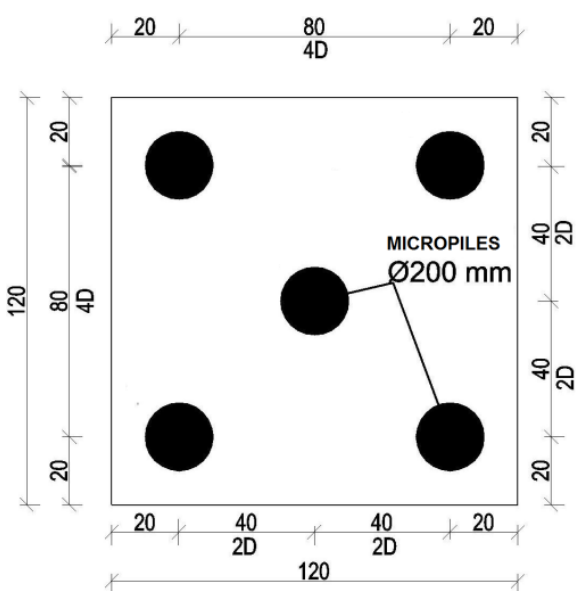

a)

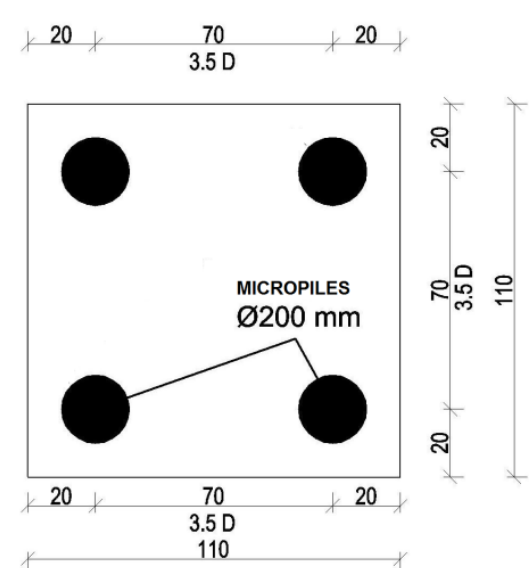

(b)

Fig.8 - Central foundation, five micropiles group (a) and marginal foundation, four micropiles group (b)

Soil was defined as Mohr-Coulomb model. This is an elastic perfectly plastic model and is defined in the same way of Plaxis 2D model: Young's module (E), Poisson's coefficient (v), cohesion (c), the friction angle and the dilatancy $(\phi, \psi)($ tab.2). The pile was modeled as linear elastic non-porous, a model that represents Hooks low of isotropic linear elasticity, the model involves two elastic stiffness parameters, Young modulus and Poisons ratio (tab.3). Piles were introduced as "beam" elements. Micropile rigidity must be well defined so that element failure does not happen before the failure of the soil.

After we introduced the input parameters for the soil and foundation, generated mesh, the program defined automaticaly the "pile-soil" interaction, by creating new "nodes" and new "conections" between these nodes and the existing mesh, wich defined the soil and the pile. So it results an elasto-plastic model to simulate the structural behavior of the interface area between micropile and the terrain. This is the side friction (in units of force per length) and the base resistance (in units of force), which sum represents the bearing capacity of the element. For analyse the elasto-plastic model, wich simulate the structural behavior of the interface zone of micropile, a failure criterion is applied. Side friction of pile appeares as a „slip" between pile and soil nodes. In Plaxis $3 \mathrm{D}$, side friction is defined automaticaly by $\mathrm{R}_{\text {inter }}$ factor. The value of this factor influences the relative displacement between the pile and the ground when the pile is subjected to axial load.[10].

Table 2

Soil parameters introduced in Plaxis 3D model

\begin{tabular}{|c|c|c|c|c|c|c|c|c|c|c|c|c|c|c|c|c|c|}
\hline ID & Name & Type & $\begin{array}{c}\gamma_{\text {unsat }} \\
{\left[\mathrm{NN} / \mathrm{m}^{3}\right]}\end{array}$ & $\begin{array}{c}\gamma_{\text {sat }} \\
{\left[\mathrm{NN} / \mathrm{m}^{3}\right]}\end{array}$ & $\begin{array}{c}\mathrm{k}_{\mathrm{x}} \\
\text { [m/day] }\end{array}$ & $\begin{array}{c}\mathrm{k}_{\mathrm{y}} \\
\text { [m/day] }\end{array}$ & $\begin{array}{c}k_{z} \\
\text { [m/day] }\end{array}$ & $\begin{array}{l}v \\
{[-]}\end{array}$ & $\begin{array}{c}E_{\text {ref }} \\
{\left[\mathrm{NN} / \mathrm{m}^{2}\right]}\end{array}$ & $\begin{array}{c}c_{\text {ref }} \\
{\left[\mathrm{NN} / \mathrm{m}^{2}\right]}\end{array}$ & $\begin{array}{l}\varphi \\
{\left[{ }^{\circ}\right]}\end{array}$ & $\begin{array}{l}\psi \\
{\left[{ }^{\circ}\right]}\end{array}$ & $\begin{array}{c}\mathrm{E}_{\mathrm{incr}} \\
{\left[\mathrm{NN} / \mathrm{m}^{3}\right]}\end{array}$ & $\begin{array}{c}c_{\text {incr }} \\
{\left[\mathrm{NN} / \mathrm{m}^{3}\right]}\end{array}$ & $\begin{array}{l}y_{\text {ref }} \\
\text { [m] }\end{array}$ & $\begin{array}{l}\text { T-Strength } \\
{\left[\mathrm{NN} / \mathrm{m}^{2}\right]}\end{array}$ & $\begin{array}{l}R_{\text {inter }} \\
{[-]}\end{array}$ \\
\hline 1 & SALT & Drained & 21.0 & 21.0 & 0.0000 & 0.0000 & 0.0000 & 0.25 & $3 E 7$ & 5.ZE3 & 30.0 & 0.0 & 0.0 & 0.0 & 0.0 & 0.0 & 1.00 \\
\hline 2 & CLAY I & Drained & 16.0 & 16.0 & 0.0000 & 0.0000 & 0.0000 & 0.35 & 8500.0 & 53.0 & 17.0 & 0.0 & 0.0 & 0.0 & 0.0 & 0.0 & 1.00 \\
\hline 3 & CLAY 2 & Drained & 18.0 & 18.0 & 0.0000 & 0.0000 & 0.0000 & 0.35 & 12500.0 & 31.0 & 15.0 & 0.0 & 0.0 & 0.0 & 0.0 & 0.0 & 1.00 \\
\hline 4 & BRECCLA & Drained & 18.5 & 18.5 & 0.0000 & 0.0000 & 0.0000 & 0.30 & 20000.0 & 20.0 & 20.0 & 0.0 & 0.0 & 0.0 & 0.0 & 0.0 & 1.00 \\
\hline
\end{tabular}

Micropiles and foundation postament characteristics for Plaxis 3D model

\begin{tabular}{|c|c|c|c|c|c|c|c|c|}
\hline ID & Name & Type & $\begin{array}{c}\mathrm{EA} \\
{[\mathrm{kN} / \mathrm{m}]}\end{array}$ & 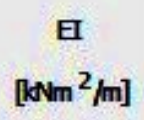 & $\begin{array}{c}w \\
{\left[k N / m^{2}\right]}\end{array}$ & $\begin{array}{c}v \\
{[-]}\end{array}$ & $\begin{array}{c}\mathrm{M}_{\mathrm{p}} \\
{[\mathrm{kNm} / \mathrm{m}]}\end{array}$ & $\begin{array}{c}\mathbf{N}_{\mathbf{p}} \\
{[\mathrm{kN} / \mathrm{m}]}\end{array}$ \\
\hline 1 & MICROPILES & Elastic & $6.2 \mathrm{E} 6$ & 20667.0 & 5.0 & 0.20 & 1E15 & $N / A$ \\
\hline 2 & FOUNDATION & Blastic & $1.28 \mathrm{E} 7$ & 1.7067 5 & 10.0 & 0.20 & 1F15 & $N / A$ \\
\hline
\end{tabular}



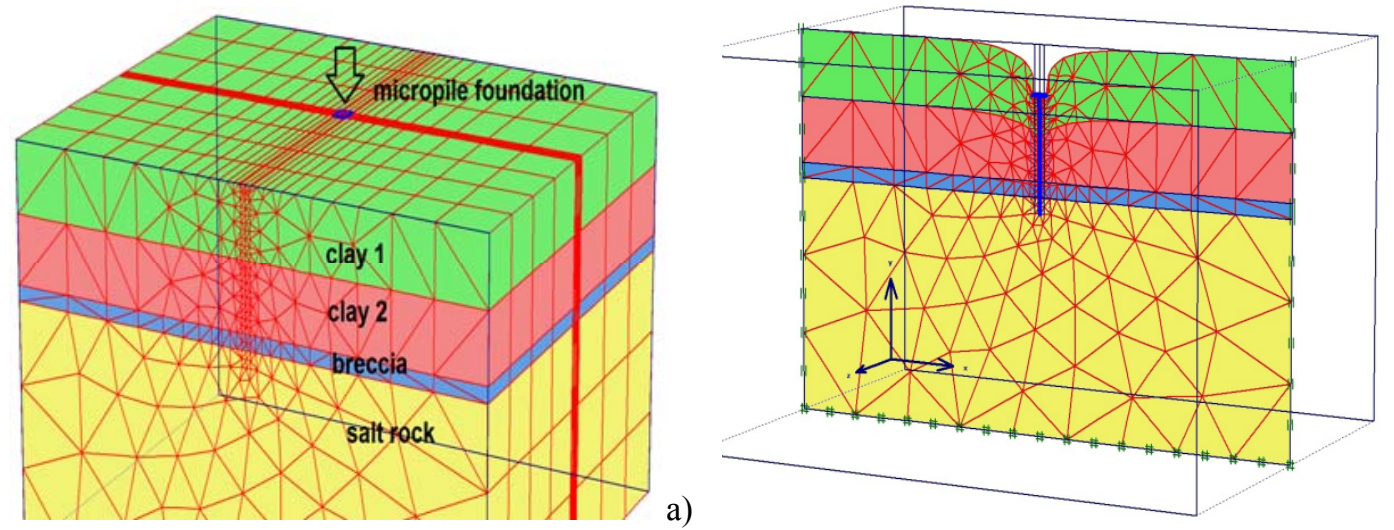

b)

Fig.9 - Calculation model for micropile group (a) and sectional plan of deformed mesh model

(b) (Phase 2) [3]

After we defined the computing models, in phase 3 we introduced the structural loads, reduced at the foundation. In Figure 10 we see the total displacements values for central and marginal foundation on micropiles (group on five and respectively four micropiles).

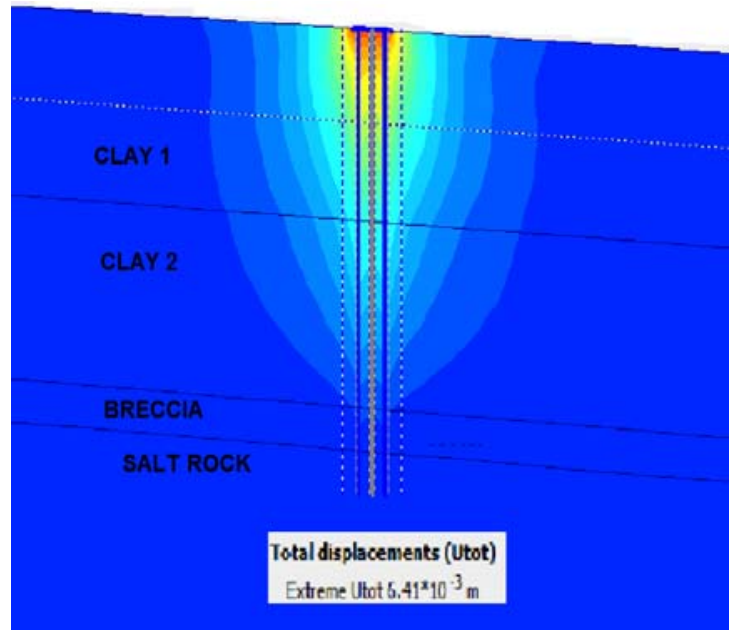

a)

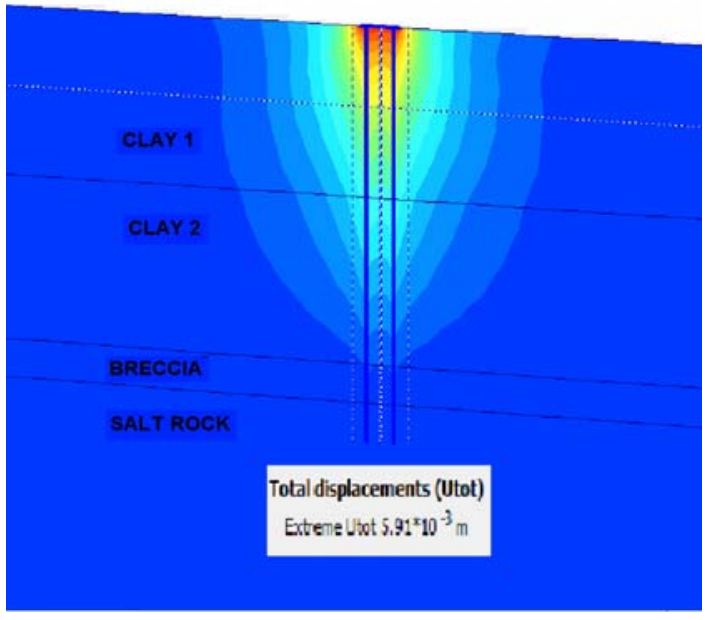

b)

Fig.10 - Total displacements values for micropiles group: (a) group of five micropiles for central foundation ;

(b) group of four micropiles for marginal foundation

The value of axial force reduced to the foundation plan, from structural loads, was $600 \mathrm{kN} / \mathrm{m} 2$ for central foundation and $450 \mathrm{kN} / \mathrm{m} 2$ for the marginal one.

In the first case, before calibrated model, the values of total displacements were $6.41 \mathrm{~mm}$, for the group of five micropiles (fig.10 a) and $5.91 \mathrm{~mm}$ for the group of four micropiles (fig.10 b). For one micropile in a group the value was $5.89 \mathrm{~mm}$ and respectively $6.38 \mathrm{~mm}$, which is a higher value in comparision with the in-situ test results obtained.

After we calibrated the model, the results obtained were: for a micropile in the central foundation, displacement value was $1.25 \mathrm{~mm}$ and the axial force $814.86 \mathrm{kN} / \mathrm{m}$ (fig.11.a) and for a micropile in the marginal group, displacement value was $1.35 \mathrm{~mm}$ with axial force 779.49 $\mathrm{kN} / \mathrm{m}$ (fig. $11 \mathrm{~b}$ ). Considering the results obtained by the in-situ tests, for micropile 97: $1.24 \mathrm{~mm}$, for micropile $71: 1.36 \mathrm{~mm}$, the calibrated model can be validated.

For the groups of five and four micropiles were obtained higher values of $0.02 \mathrm{~mm}$, compared with the values obtained for one micropile in a group, respectively: $1.27 \mathrm{~mm}$ the values of total displacement for the central group (fig.12 a) and $1.37 \mathrm{~mm}$ for the marginal one (fig.12 b). Values obtained for horizontal displacements were insignifiant, and also for moments and shear forces. 


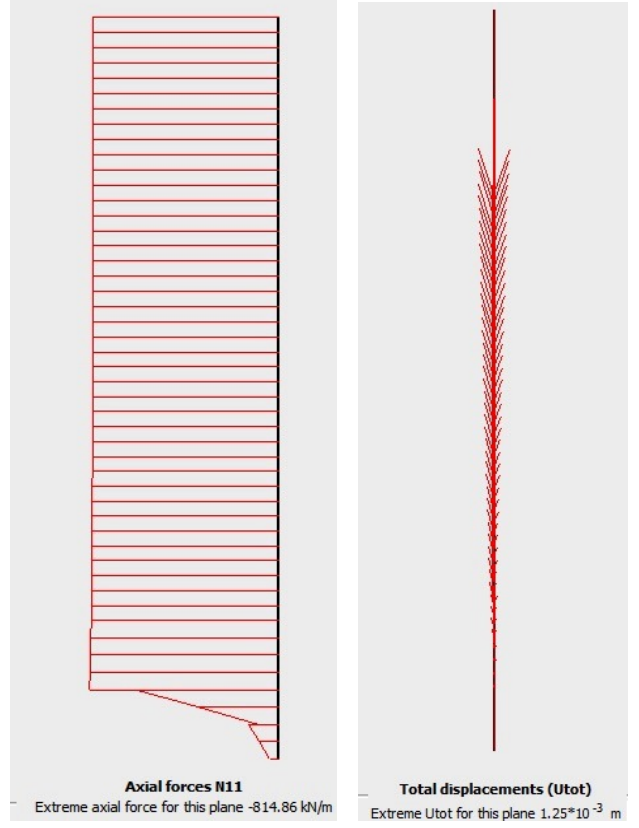

a)
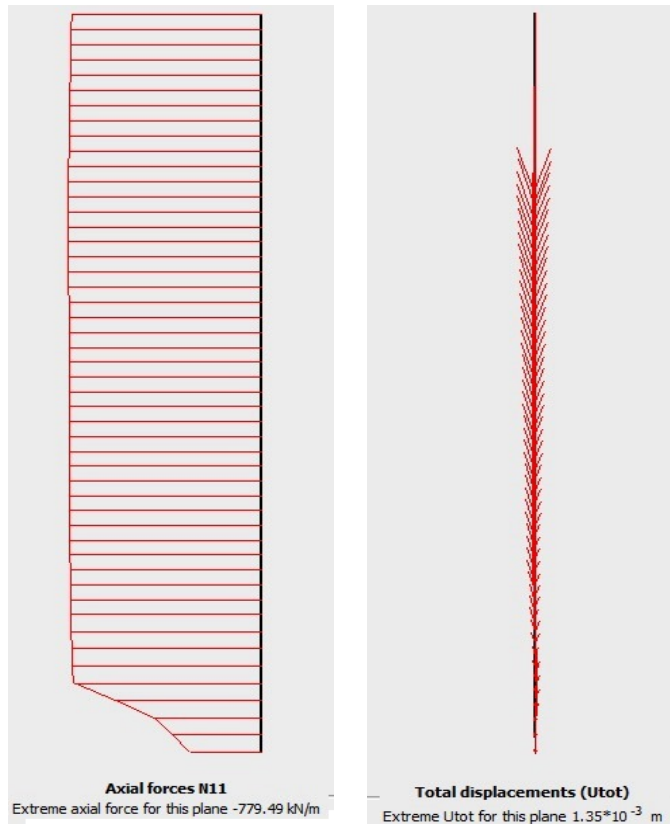

b)

Fig.11 - Final results obtained for axial force and displacements in micropiles group, Plaxis 3D calibrated model: a) micropile in the central group of foundation ; b) micropile in the marginal group of foundation

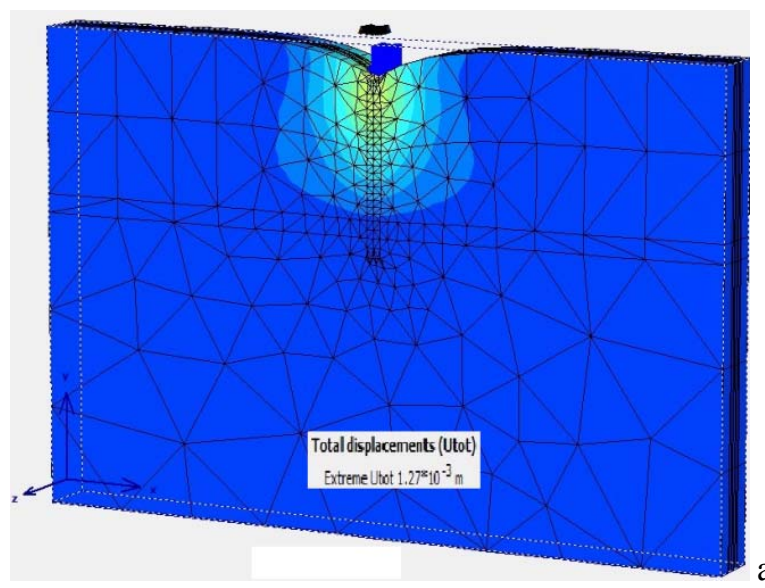

b)

Fig.12 - Total displacements for groups on micropiles: (a) five micropiles group; (b) four micropiles group

Whether they are willing in a group or in a network, micropiles formes with adjacent soil, a "composite block", which means that the estimated capacity of the group or network is not necessarily the sum of the individual capacities of each isolated element. Piles influence each other, especially since the distance between them is smaller, causing overlapping active zones, thereby increasing settelment and decreasing bearing capacity of the group. In this case, with the distance between the micropiles of central group by $2 \mathrm{~d}$ and for the marginal by $3.5 \mathrm{~d}$ (where „d" is the distance between micropiles in a group, as is defined in Figure 8), the settelment of micropiles group is higher by $0.02 \mathrm{~mm}$ to the values obtained for the isolated element and this is because the group effect.

\subsection{Calculation model and results obtained for the foundation on micropiles}

MIDAS GTS NX allows the creation of model calculations accurately, compared with Plaxis 3D. The mathematical model was created after the lithologic profile I-I, for the Main Building, as we 
presented in Figure 3. This profile was processed in a CAD file and then imported into MIDAS GTS-NX. The structural informations, for micropiles and foundations were similar with introduction parameters in Plaxis 3D.

The interface model is based on Coulomb's law of friction (1785) and may be defined in the program by an empirical formula, uses a virtual thickness $\left(t_{v}\right)$ and strength reduction factor $(\mathrm{R})$ [11]. In our model, the interface was automaticaly calculated, according to the element properties of the neighboring ground element, using the two mentioned parameters, introduced $\mathrm{t}_{\mathrm{v}}=0.1$ and $\mathrm{R}=1$. Mention here that it is about the interval of values for the strength reduction factor, defined in the program, for clay-concrete interface, between 1...0.7.Creating calculation model followed several variants to its calibration. Data entry steps for creating the calculation model were:

- Stage 1: Defining the soil layers: clay layer 1, clay layer 2, breccia (fractured and altereted rock) and the layer of rock salt,

- Stage 2: Micropiles introduction in the terrain, by simulating the embeddment in salt rock layer, one meter,

- Stage 3: Introduction of stiffening elements : foundations beam and base plates,

- Stage 4: Application of structural loads reduced at foundation base. For the computing model created, analysis was done for the second axis of ten foundations in the longitudinal direction (Figure 13).

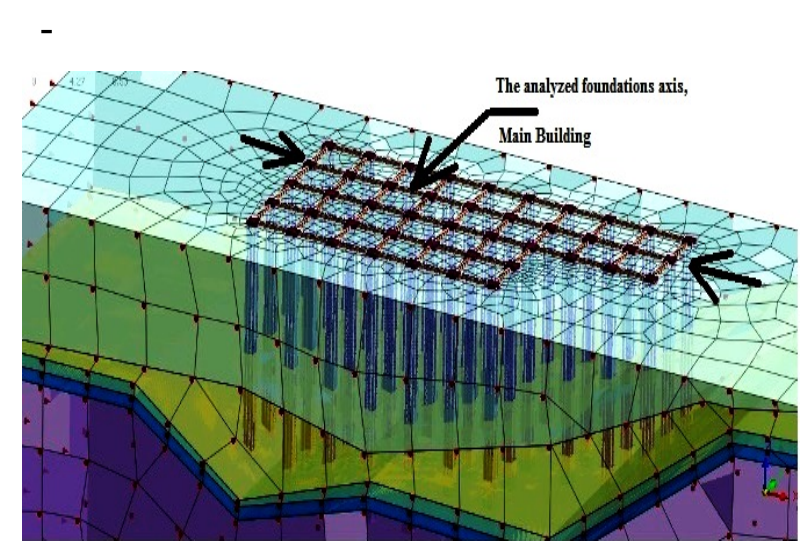

(a)

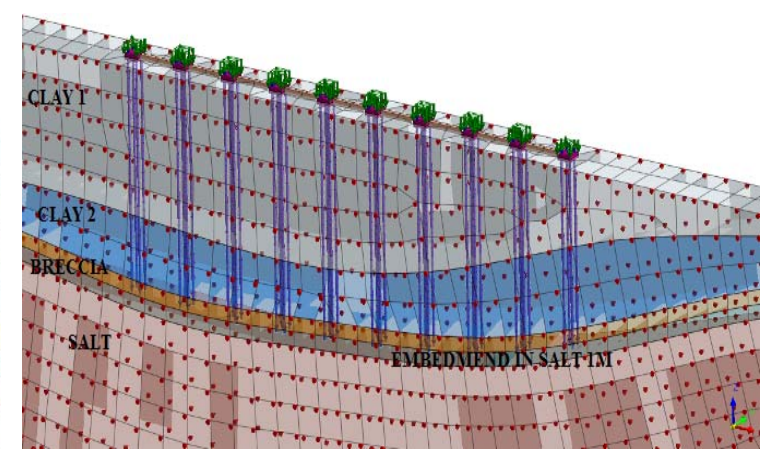

(b)

Fig.13 - The mathematical model for the foundations on micropiles: a) the entire foundation for Main Building; b) the analyzed axis of foundation on micropiles (MIDAS GTS-NX)

It has paid particular attention to modeling the base layer of salt rock which are embedded micropiles and which gives them superior properties of behavior on axial forces.

As noted in previous study, embedding in layer of salt rock gives micropile behavioral characteristics similar to those obtained by postgrouting: low displacements values under vertical loads, for drilled micropile (type A) embedded in salt, compared to type B -postgrouted micropile in soft clays [1].

Calibration computing model followed 23 variants, by modeling the salt layer with Mohr-Coulomb failure criterion, Mohr-Coulomb failure criterion structural, as a weak concrete, (fig.14) or defined it with Hoek-Brown failure criterion. In the first cases of analysis the maximum values obtained for micropiles displacements were between $13.6 \mathrm{~mm}$, with axial forces value $110 \mathrm{kN}$, and respectively, $10.5 \mathrm{~mm}$ with axial forces value $89 \mathrm{kN}$. It was observed insignifiant differences of values between Stage 2 (introduction of micropiles in terrain) and Stage 3 ( introduction of stiffness elements : foundations beams and postaments), so we concluded the two stages may be cumulated into one. After we modeled the micropiles embeding in salt layer, the results obtained 
were satisfacatorily: for micropiles, the maximum displacements results were $1.77 \mathrm{~mm}$, and the maximum axial force values in the elements was $145 \mathrm{kN}$.

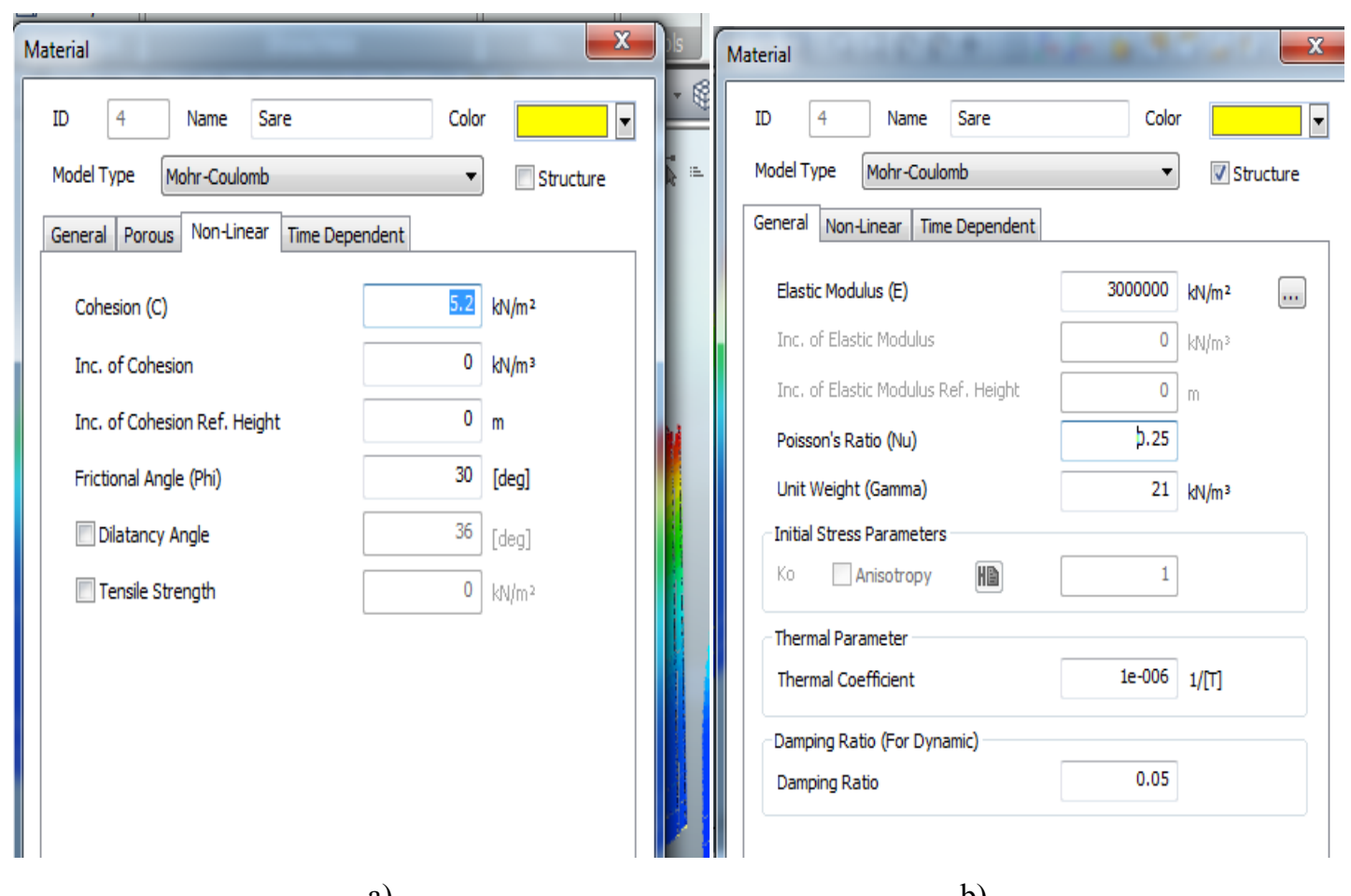

a)

b)

Fig.14 - Salt layer model: a) Mohr Coulomb non-linear model ; b) Mohr-Coulomb structural model (MIDAS GTS-NX)

The maximum values of displacements, both for land and for micropiles, touched in the end zones of marginal foundations (Figure 15). This is because the length of micropiles to the salt layer and is higher in the left zone of the analyzed foundations axis. The values of axial forces in micropiles of marginal foundations were $145 \mathrm{kN}$, to estimated values from structural loads which is $110 \mathrm{kN}$.

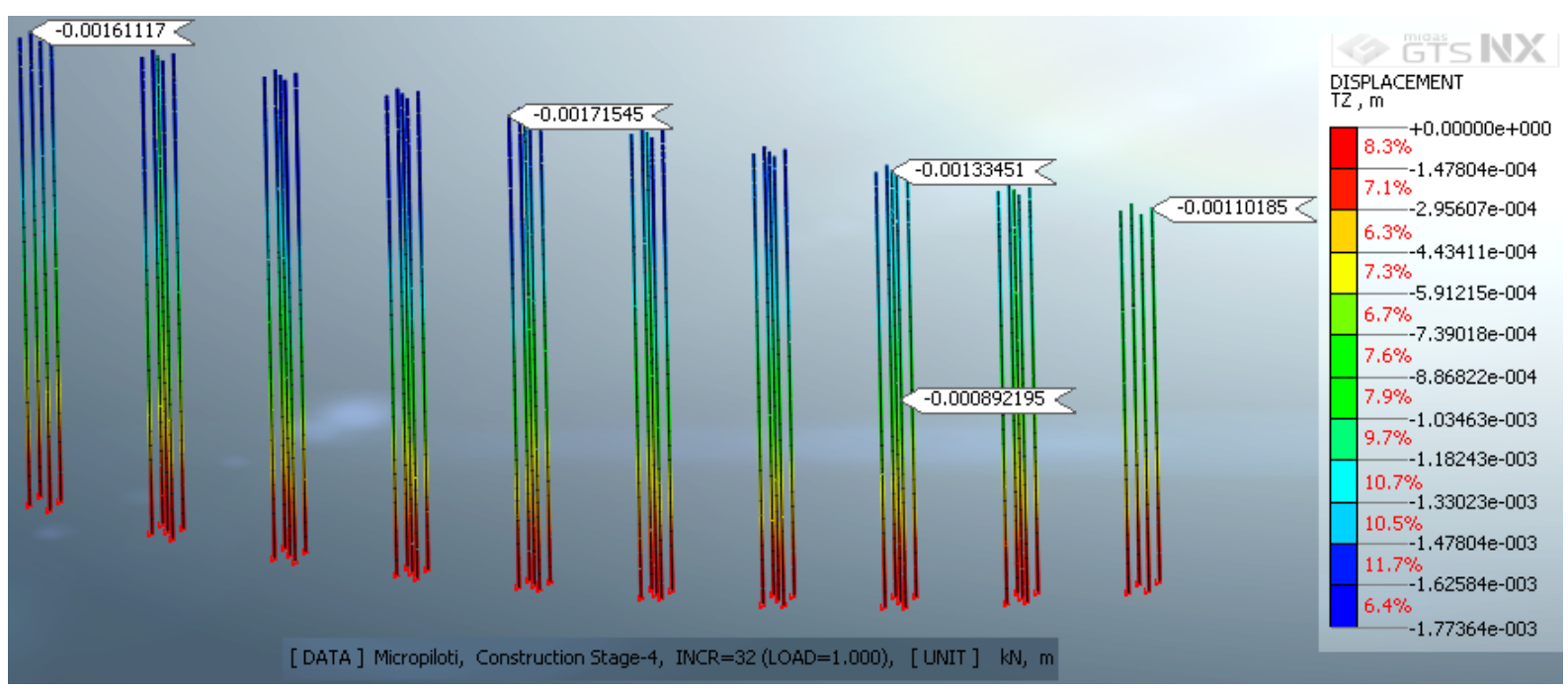

Fig.15 - Displacements of micropiles in $\mathrm{Z}$ direction, under axial forces, from structure, reduced at the foundations base (results obtained with MIDAS GTS-NX model)

In the diagram of displacements, in $\mathrm{Z}$ direction of micropiles (fig.15), we can see the maximum value is $1.77 \mathrm{~mm}$. The values obtained are closed to the in-situ tests results, and this is the principal reason for validating this calculate model. We can see next, the diagram of total displacements on micropiles (fig.16), and observe values of $3 \ldots 4 \mathrm{~mm}$ on the marginal groups of 
foundation on micropiles, resulted especially, from the displacements in $\mathrm{X}$ direction. We mentioned here, the values obtained for the displacements in $\mathrm{Y}$ directions are insignificants.

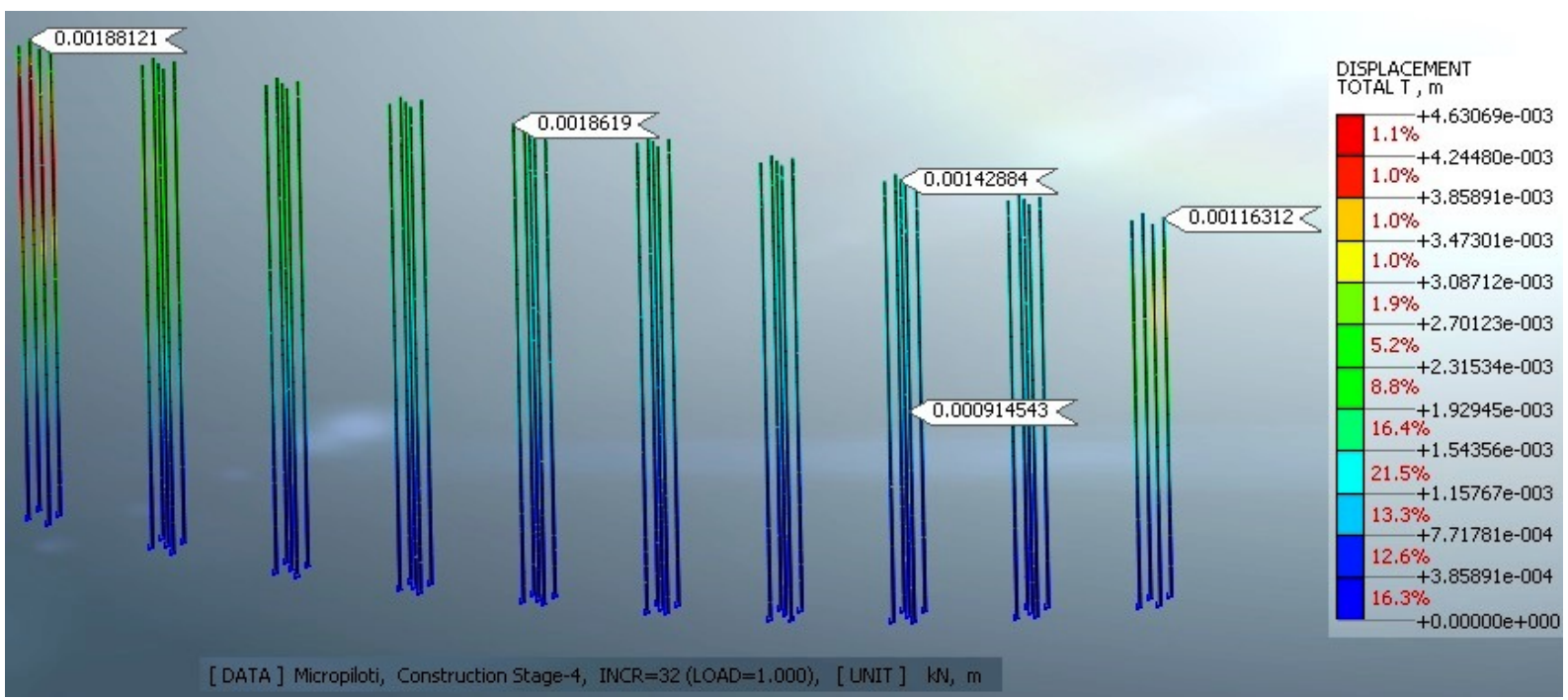

Fig.16 - Total displacements of micropiles, under axial forces, from structure, reduced at the foundations base (results obtained with MIDAS GTS-NX model)

For the soil displacements, the values obtained in $\mathrm{Z}$ direction, were similar to the total displacements values (fig.17). The obtained values from total soil displacements were approximately $2 \mathrm{~cm}$ (Fig.17), and the maximum of this value was touched in the foundations marginal zones.

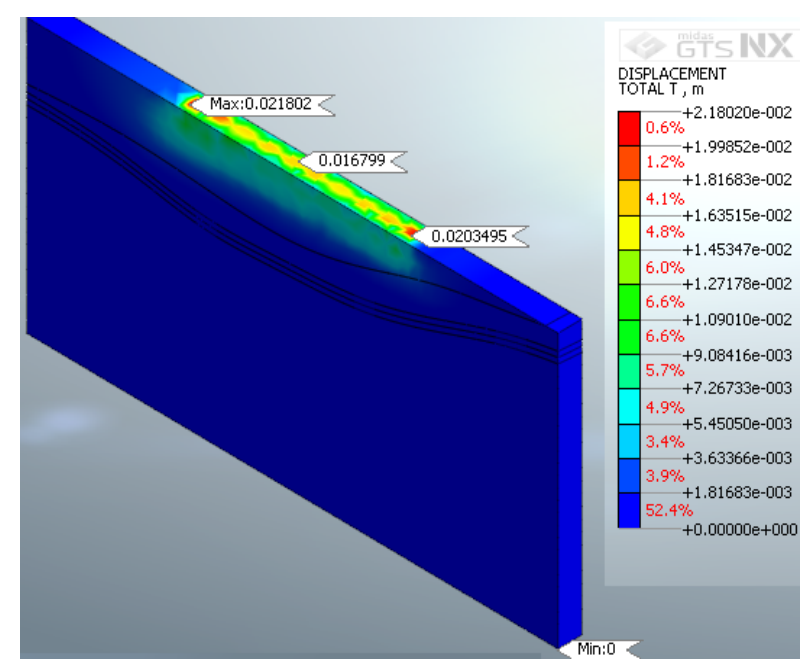

a)

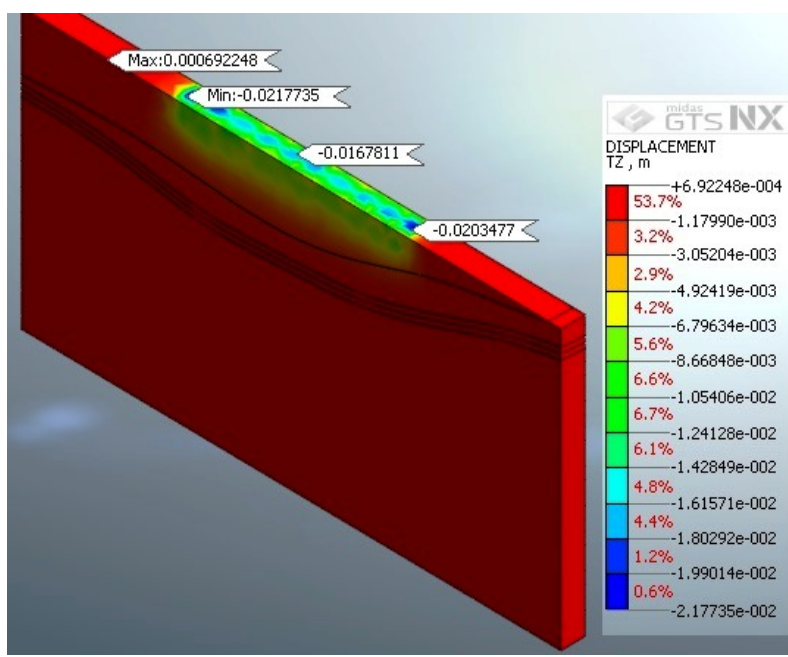

b)

Fig.17 - (a) Total displacements of the soil; (b) Vertical displacements of the soil (results obtained with MIDAS GTS-NX model)

For this calculate model we apreciated, its accuracy may be improved, esspecially for soil model, to obtain values less than $2 \mathrm{~cm}$. Also, the micropiles of the left marginal group must be verify at buckling, because of the results obtained and revealed in diagram of displacements in $Z$ direction.

\section{Interpretation and validation of the results obtained on calculation models}

The results obtained with the calculation model PLAXIS 2D, can be validated if we take into consideration the placement of the micropiles in saline karst, together with the results obtained 
for the micropile 178, and also the comparison to the results obtained with ALPAXL (Prezzi, 2008) - created for micropiles axially loaded and validated through the in-situ tests.[3]

In the case of the calculation model and the results obtained with the program PLAXIS 3D, it was necessary to check and recalibrate the model, due to the first set of results obtained that could not be validated. The results obtained in the final variant are close to the ones on site-tests, so the calculation model can be validated. Thus, after the recalibration of the calculation model the best results were obtained with the program PLAXIS 3D.[3]

In the case of modeling the foundations on micropiles with the program MIDAS GTS-NX, the results are acceptable in comparison to those obtained through experimental tests for the micropiles of the central foundations. The maximum values of total displacements, on site and for micropiles, are touching in the end zones, the areas of the marginal foundations. These maximum values are given especially by the length of the micropile up to the embedment in the salt rock layer and appear especially on the left side of foundations axis, where the depth to the salt is bigger, comparatively to the area on the right side of the analyzed foundations. The results are within a reasonable interval of values, comparable to those obtained on site through tests. The displacement of the soil has values of $2 \mathrm{~cm}$. The calculation model, created with MIDAS GTS-NX can also be validated, considering the results obtained.[3]

\section{Conclusions}

Three calculation models have been created for the validation, based on the in-situ tests, for axially loaded micropiles of $200 \mathrm{~mm}$ diameter, embedded in salt rock.

The analysis for a micropile has been done on the model created by the program PLAXIS 2D, and the results obtained were satisfactory, considering the results obtained on site for micropile 178 , which supposedly crossed a layer of soft clay up to the salt, so that the final displacement from the tests had a value of $2.35 \mathrm{~mm}$ and the average of the vertical displacements for the same values of the axial loads of $210 \mathrm{kN}$ is approximately $2.00 \mathrm{~mm}$. In the case of the other three micropiles, the values obtained from the calculation models are suitable. The results obtained in the two dimensional model are comparable to those obtained by analysis with the ALPAXL 1.0 spreadsheet. As a result, the calculation model can be validated, if we take into account the unpredictability of karstic terrains, compared to other difficult foundation terrains.[3]

Regarding the results obtained in the three dimensional model PLAXIS 3D, for the groups of four or five micropiles, of marginal and, respectively, central foundations, the results obtained, from structural loads, and reduced to the base of the foundations, there have been obtained values of the displacements on the micropiles of the foundation groups close to the ones on site, of $1.25 \mathrm{~mm}$ and $1.35 \mathrm{~mm}$ respectively. As the results on site for the micropile of the central group were of $1.24 \mathrm{~mm}$ at the maximum axial test, we notice that from PLAXIS 3D revised calculation model, the best results have been obtained. Therefore, the PLAXIS 3D model can be validated.[3]

The results obtained with MIDAS GTS-NX model, are acceptable and the calculation model for micropiles can be validated. There were obtained total displacements values having the maximum of $4.6 \mathrm{~mm}$ for the micropiles of the marginal foundations group, and of about $2 \mathrm{~mm}$ for the micropiles of the central foundations group. The displacements of the soil have greater values at the ends of the foundations, which means that the accurate modeling of the foundation soil can be improved. The results obtained on the calculation models are considered to be acceptable.[3] 


\section{References}

[1]. Radan, G. (2014). Micropiles axially loaded in karst terrain. Mathematical Modelling in Civil Engineering, Special Issue, Y.R.C. 2014,from http://mmce.rs.utcb.ro/wiew-articles/archive1/18-2014/58-scientific-journal-specialissue1.html.

[2]. Seo, H. \& Prezzi, M. (2008). Use of Micropiles for Foundations of Transportation Structures Final Report. Joint Transportation Research Program: Purdue University.

[3]. Radan, G. (2015). Methods of foundation and stabilization of terrains with micropiles. Unpublished Doctoral Thesis, Technical University of Civil Engineering Bucharest, Romania.

[4]. Schein, T. (2008). Geotechnical Expertise Report, Slanic Prahova county. No. 275-EG/November 2008. Timisoara.

[5]. Arad S., Arad V., Onica I., Oprina A. \& Chipesiu F. (2010). Stability Study for a Large Cavern in Salt Rock from Slanic Prahova. Acta Physica Polonica B, Vol.41(2010),No.7.

[6]. SC All Inclusive SRL. (2009). Testing Report with static vertical forces to axial compression drilled micropile , Slanic-Prahova, Baia-Verde. No 174/05.03.2009. Bucharest.

[7]. Seo H., Prezzi M. \& Salgado R. (2013). Instrumented static load tests on rock-socked micropile. Journal of Geotechnical and Geoenvironmental Engineering. DOI:10.1061/(ASCE)GT.1943-5606.0000946.

[8]. Salgado R., Prezzi M. \& Seo H. (2007). Advanced Modeling Tools for the Analysis of axially Loaded Piles. Advances in Deep Foundations. International Workshoop on Recent Advances of Deep Foundations (IWDPF07) 1-2 Febr.2007,pg 49-67, print ISBN: 978-0-415-43629-8, e-Book ISBN: 978-0-203-93841-6, DOI: 10.1201/9780203938416.ch3.

[9]. Wolosick J.R., Bonar E. \& Nufer P.J. (2007). Micropile foundation repair and underpinning, Arts and Science Museum, University of Puerto-Rico, Mayaguez. $8^{\text {th }}$ International Workshop on Micropiles, Toronto, 2007, from http://www.ismicropiles.org.

[10]. Dao, T.P.T.(2011). Validation of Plaxis embedded piles for lateral loading. MSc Thesis. Delft University of Technology

[11]. MIDAS Engineering Software, from http://en.midasuser.com/product/gtsnx_overview.asp

[12]. Elkasabgy M. \& El Naggar M.H. (2007). Finite element analysis of the axial capacity of micropile.IWM,Toronto,Canada2007,from http://www.ismicropiles.org

[13]. Elarabi, H. \& Alhadi Alshareef M. Numerical Analysis of Failure Mode of Micropile in Cohesive Soil. (2014). BRR Journal, BRRI, U. of K., Vol. xx, month 2014, from http://khartoumspace.uofk.edu.

[14]. Plaxis 2d Tutorial Manual (2015), from http://www.plaxis.nl/plaxis2d/

[15]. Bivens, M.J. \& Siegel, T.C. (2007). Case histories of micropile in karst : The influence of installation on design performance. GSP 158 Contemporary Issues in Deep Foundations, GeoDenver Conference, Geotechnical Special Publication No. 158, ASCE. 